\title{
Ice-on and ice-off dynamics of ciliates and metazooplankton in the Luczański Canal (Poland)
}

\author{
Krystyna Kalinowska • Maciej Karpowicz $\mathbb{D}$
}

Received: 8 May 2020/Accepted: 21 August 2020/Published online: 1 September 2020

(C) The Author(s) 2020

\begin{abstract}
The ciliate-metazooplankton trophic coupling is well documented from both laboratory and field experiments. The knowledge about these relationships during winter ice-covered periods is very scarce. The abundance and composition of planktonic ciliates, rotifers and crustaceans were studied during the ice-covered and ice-free periods in the Łuczański Canal (Masurian Lakeland, Poland). We hypothesised that in winter, rotifers play a major role in the topdown control of ciliates and that ciliate-metazooplankton relationships differ not only between the icecovered and ice-free periods, but also between icecovered months. Our study showed that ciliates formed a significant part of zooplankton biomass during the winter ice-covered period when crustaceans occurred in very low abundances. Despite cold water temperature and the presence of ice cover, time was probably a cue that initiates zooplankton development. The ciliate, rotifer and crustacean numbers and biomass, as well as chlorophyll $a$ concentrations, were
\end{abstract}

Handling Editor: David Montagnes.

K. Kalinowska ( $₫)$

Department of Lake Fisheries, Inland Fisheries Institute in

Olsztyn, Rajska 2, 11-500 Giżycko, Poland

e-mail: k.kalinowska@infish.com.pl

M. Karpowicz

Department of Hydrobiology, Faculty of Biology, University of Białystok, Ciołkowskiego $1 \mathrm{~J}$,

15-245 Białystok, Poland lower in February than in ice-free periods. In the winter month with ice cover, bottom-up control by resources was more important than top-down control by zooplankton grazing in regulating ciliates. In the spring month with ice cover, crustaceans and rotifers may include ciliates as an important part of their diets. In April, the studied groups of organisms were not related to each other in contrast to the summer, when zooplankton communities were closely related to each other. In autumn, rotifers may play an important role in controlling ciliates. The abundance, composition and ciliate-metazoan relationships can vary considerably not only across seasons, but also across ice-covered months.

Keywords Ice cover - Ciliated protozoa - Rotifers . Crustaceans $\cdot$ Community composition $\cdot$ Trophic coupling

\section{Introduction}

Ciliates play a significant role in the pelagic food web of freshwater ecosystems. They are consumers of aquatic bacteria (especially in eutrophic waters), autotrophic eukaryotic picoplankton, microalgae, heterotrophic nanoflagellates and even small rotifers (see Foissner et al. 1999). They also play an important role in the processes of nutrient regeneration 
(Ejsmont-Karabin et al. 2004) and degradation and mineralisation of organic matter (Chróst et al. 2009). As a significant component of the microbial loop, they constitute a link between both dissolved organic matter and bacteria and metazooplankton. It is well documented from both laboratory and field experiments that ciliates are a valuable, but still not appreciated, food resource for metazooplankton, including rotifers (Arndt 1993; Weisse and Frahm 2001; Ventelä et al. 2002; Bielańska-Grajner et al. 2011), cladocerans and copepods (e.g. Carrick et al. 1991; Sanders and Wickham 1993; Wiackowski et al. 1994; Zöllner et al. 2003; Wiąckowski and KocerbaSoroka 2017; Moore et al. 2019), and fish larvae (Zingel et al. 2019), due to the considerable contents of polyunsaturated fatty acids (PUFA) and sterols (Sommer et al. 2012; Makhutova et al. 2013) as well as nitrogen and phosphorus (Martin-Creuzburg et al. 2005). Thus, small ciliates may enrich the diet of consumers even when they constitute only a minor part of the carbon diet (Sommer et al. 2012).

Metazooplankton, both small-sized crustaceans (Agasild et al. 2013) and large-bodied crustaceans (Kalinowska et al. 2015), can strongly affect the abundance, biomass, species composition and functional role of ciliates (Sanders and Wickham 1993; Wiackowski et al. 1994; Adrian and Schneider-Olt 1999; Hansen 2000; Li et al. 2017). The impact of small-bodied crustaceans and rotifers on ciliates is selective and leads to the shifts in species structure rather than a significant reduction in numbers (Wiąckowski 2000). Large-bodied Daphnia species, due to their ability to filter a wide range of food particle sizes, can significantly reduce the abundances of ciliates and other microbial loop components by predation, interference or exploitative competition for the same resources (Jürgens 1994; Jack and Gilbert 1997; Kopylov and Kosolapov 2011). Cyclopoid and calanoid copepods may consume ciliates preferentially over phytoplankton and nanoflagellates (Burns and Gilbert 1993; Brett et al. 1994; Adrian and Schneider-Olt 1999; Burns and Schallenberg 2001; Moore et al. 2019). Most of the studies mentioned above were carried out particularly in summer, while the relationships between ciliates and metazooplankton in freshwater systems have rarely been studied in winter ice-covered periods when the numbers of crustaceans are normally low (Virro et al. 2009;
Kalinowska and Grabowska 2016; Kalinowska et al. 2017, 2019).

Environmental parameters can strongly influence the distribution, biomass and dynamics of planktonic organisms during winter (Sommer et al. 2012; Bertilsson et al. 2013). It is suggested, however, that grazing pressure by rotifers and copepods and food availability may be more important than abiotic factors in controlling the growth of ciliates in eutrophic lakes under the ice (Kalinowska et al. 2019). As shown by Agbeti and Smol (1995), although zooplankton abundance during the ice-covered period is low, their potential grazing impact during this period cannot be completely ignored, especially in the era of global warming. Knowledge about ciliatemetazoan relationships is important for the understanding of energy and material flow in food webs. So far, there is no information about zooplankton abundance and structure in canals of temperate climatic zones.

The main aim of this study was to determine the seasonal variations in the abundance and species composition of ciliates, rotifers and crustaceans during the ice-covered and ice-free periods (spring, summer, autumn) in the Łuczański Canal (The Great Masurian Lakes system, Poland). During the ice-covered period, rotifers can reach high abundances (Dokulil and Herzig 2009; Kalinowska and Grabowska 2016), accounting for $80-90 \%$ of the total abundance and biomass of the winter zooplankton (Virro et al. 2009). Crustaceans are usually few or even absent under the ice and dominated by copepods, mainly juvenile forms (Ventelä et al. 1998; Dokulil and Herzig 2009; Virro et al. 2009; Twiss et al. 2012; Kalinowska and Grabowska 2016). However, some species among cladocerans (e.g. Daphnia spp., Bosmina spp.) may lead an active life under the ice cover (Grosbois et al. 2017). It is documented that winter is a very dynamic period, when planktonic communities are strongly fluctuating over the short time span (Bertilsson et al. 2013; Kalinowska et al. 2017, 2019). We hypothesise that in winter, rotifers play a major role in the topdown control of ciliates. We also assumed that ciliatemetazooplankton relationships differ not only between the ice-covered and ice-free periods, but also between winter months. 


\section{Materials and methods}

Study area, sample collection and environmental parameters

The study was conducted in the Łuczański Canal (Masurian Lakeland, north-eastern Poland), which has a total length of $2130 \mathrm{~m}$, width of 12-15 m and depth of $1.5-2.2 \mathrm{~m}$ (mean of $1.9 \mathrm{~m}$ ). It connects lakes Niegocin and Kisajno (Fig. 1). In summer (June to August), the canal is intensively used for fishing and sailing. Water samples were collected with a 5-L Bernatowicz sampler once a week in February (winter), March (spring month with ice cover), April (spring), July (summer) and October (autumn) 2018, from three sites situated about $500 \mathrm{~m}$ from each other. Each month, samples were taken from a depth of $0.5 \mathrm{~m}$.

The thickness of ice and snow was measured manually using a special wooden strip bent at the end. Temperature, dissolved oxygen concentrations, $\mathrm{pH}$ and conductivity were measured in situ using a YSI 6600-meter (Yellow Spring Instruments, USA). Water transparency was measured with a Secchi disc. Chlorophyll $a$ concentrations were determined by the spectrophotometric analysis of acetone extracts of algae and cyanobacteria retained on Whatman GF/C filters according to Golterman (1969).
Ciliate enumeration and identification

Ciliate samples ( $1 \mathrm{~L})$ were fixed with Lugol's solution ( $0.5 \%$ final concentration), allowed to settle for $48 \mathrm{~h}$ at $4{ }^{\circ} \mathrm{C}$ in the dark, and then decanted to $5-10 \mathrm{~mL}$ (depending on ciliate density and the concentrations of other particles). Ciliates in $100 \mu \mathrm{L}$ of the concentrated sample were examined under a light microscope (Nikon Eclipse E200). Three microscopic slides were prepared from each sample. The entire slides were surveyed at 200-400× magnification. At least, 200 individuals were counted. Large (usually $>100 \mu \mathrm{m}$ ) species were enumerated in a Sedgewick-Rafter counting chamber. Counts were made within 7-10 days of sampling. Species composition was determined from living material filtered through a $10-\mu \mathrm{m}$ mesh size plankton net taken each time concurrently with those for quantitative determination, using a phase-contrast, dark-field, stains for the nuclei and food vacuoles, and silver nitrate impregnation. Biovolume was calculated from measurements of cell dimensions and simple geometric shapes and then multiplied by a factor of 1.4 (Müller and Geller 1993). Ciliate identification was mainly based on Foissner et al. (1999).

\section{Metazoan enumeration and identification}

Rotifer and crustacean samples (20 L) were concentrated using a $20-\mu \mathrm{m}$ mesh plankton net and preserved

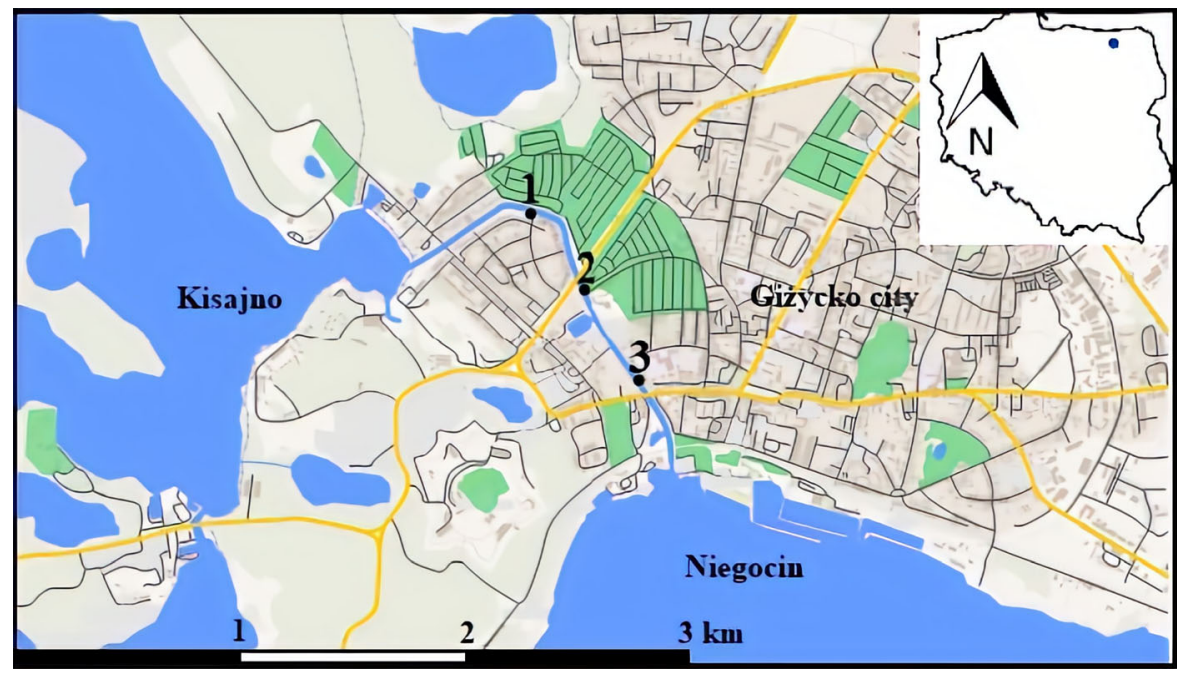

Fig. 1 Location of Łuczański Canal with the sampling sites 
with Lugol's solution (2\% final concentration) and $96 \%$ ethanol (10\% final concentration). The abundance of organisms was quantified using a Sedgewick-Rafter chamber under an optical microscope (Nikon Eclipse E200). Rotifers and crustaceans were identified to species, and all individuals in the samples were enumerated. Identification of rotifer and crustacean species was mainly based on Radwan et al. (2004) and Błędzki and Rybak (2016), respectively. Ten length measurements were also made for each species and used to estimate the wet weight of crustaceans by applying the equation from Bottrell et al. (1976). The biomass of rotifers was established following Ejsmont-Karabin (1998).

\section{Data processing}

Statistical analyses of results were carried out using STATISTICA 10.0 (StatSoft, Inc.) and Canoco 5. The differences in the physical (ice/snow cover, water temperature, electrolytic conductivity), chemical (oxygen, pH,) and biological (chlorophyll $a$, numbers and biomass of ciliates, rotifers and crustaceans) parameters between seasons were analysed using the nonparametric Kruskal-Wallis test. The nonparametric Mann-Whitney $U$-test was used to analyse the differences in the thickness of ice and snow between two winter months. Probability levels of $<0.05$ were considered significant. The biological, physical and chemical variables were correlated using principal component analysis (PCA) with a correlation matrix. Data from the three sites on each sample date $(n=12$ for each month) were used to perform statistical analyses. The coefficient of variation $(\mathrm{CV}-\%$ standard deviation of the mean) was used to compare the variability of parameters in the seasons.

\section{Results}

Environmental characteristics

In February and March, the canal was covered by ice. The thickness of ice increased gradually to a maximum of $15.7 \mathrm{~cm}$ on 6 March and then decreased to $2.7 \mathrm{~cm}$ at the end of March (Fig. 2). In February, the ice was covered with a thin layer of snow $(0.4-3.7 \mathrm{~cm})$, while in March, snow cover was about $6 \mathrm{~cm}$ thick and present only at the beginning of the

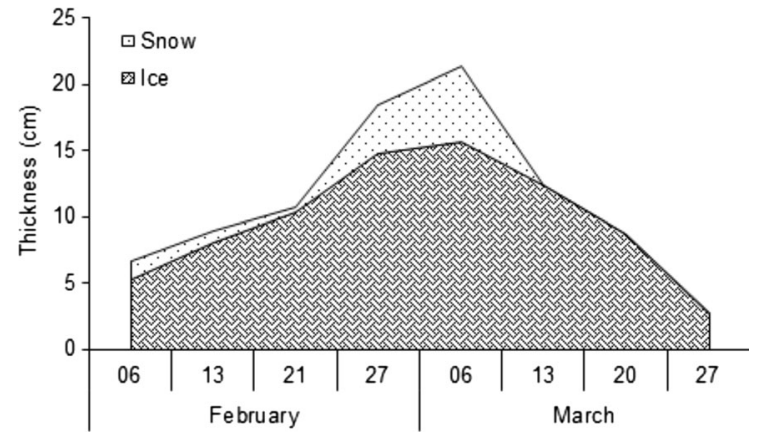

Fig. 2 The thickness of the ice and snow cover during the icecovered period in the Łuczański Canal

month. Both months did not differ significantly in the ice thickness $(U=66, p=0.73)$, but they differed significantly in snow cover $(U=36, p=0.032)$.

Mean water temperature was $0.4 \pm 0.1,1.3 \pm 0.8$, $7.0 \pm 3.6,19.5 \pm 3.4$ and $11.7 \pm 1.7{ }^{\circ} \mathrm{C}$ in February, March, April, July and October, respectively. The differences in temperature among months were significant $(Z=3.26-6.64, p<0.01)$. Oxygen concentrations ranged from $3.5 \pm 1.8$ to $11.7 \pm 0.3 \mathrm{mg} \mathrm{L}^{-1}$; both the lowest and highest values were noted in March. The differences in oxygen concentrations were statistically significant between July and October only $(Z=2.96, p=0.03)$. The values of $\mathrm{pH}$ were about 8.0-9.5 and differed significantly between July and both February $(Z=3.50, p=0.003)$ and March $(Z=3.60, p=0.002)$. Electrolytic conductivity varied from 283.3 to $321 \mu \mathrm{S} \mathrm{cm}^{-1}$ and differed significantly between July and both February $(Z=3.64$, $p=0.002)$ and April $(Z=3.75, p=0.001)$. Throughout the study, the Secchi disc visibility reached the bottom and was about $1.3-1.5 \mathrm{~m}$.

Chlorophyll a concentrations ranged from $2.35 \pm 0.1$ to $74.98 \pm 11.47 \mu \mathrm{g} \mathrm{L}^{-1}$ (Fig. 3). The lowest value was recorded in February, while the highest in July. During the ice-covered period, the concentrations increased gradually, reaching maximal value at the end of March. The highest variability (as shown by CV) both between sites (Fig. 3) and sampling dates (Table 1) were found in July (CV up to $15 \%$ and $133 \%$, respectively). The mean value in February was lower than those in other months, while in March, concentration was comparable to the values in spring and autumn (Table 1). However, statistical differences were significant only between February and other months $(Z=2.93-4.47, p<0.05)$. 


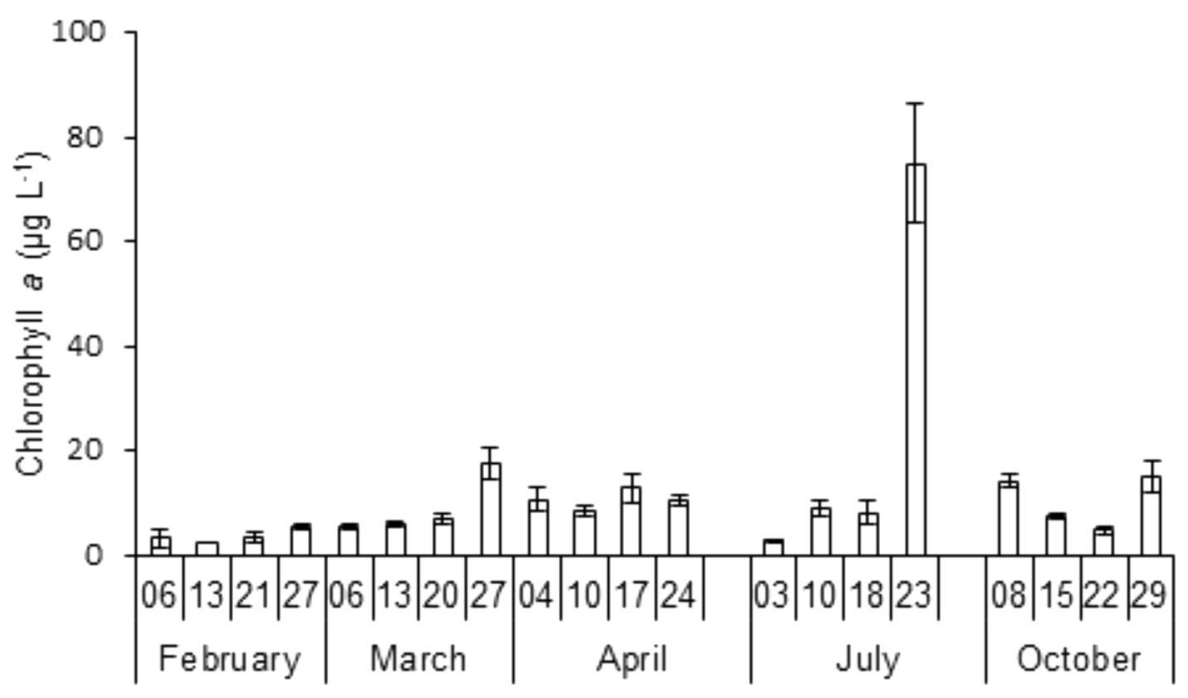

Fig. 3 Chlorophyll $a$ concentrations (mean values from 3 sites \pm standard deviations) in the Łuczański Canal

Table 1 Mean values ( \pm standard deviations) of chlorophyll $a$ concentrations, ciliate, rotifer and crustacean numbers $(\mathrm{N})$ and biomass (B) in the Łuczański Canal

\begin{tabular}{lccccc}
\hline Parameter & February & March & April & July & October \\
\hline Chlorophyll $a\left(\mu \mathrm{g} \mathrm{L}^{-1}\right)$ & $3.6 \pm 1.4$ & $8.9 \pm 5.4$ & $10.7 \pm 2.3$ & $23.6 \pm 31.5$ & $10.4 \pm 4.8$ \\
Ciliate N $\left(\times 10^{3}\right.$ ind. L $\left.{ }^{-1}\right)$ & $8.0 \pm 2.9$ & $10.4 \pm 11.7$ & $37.5 \pm 19.4$ & $12.5 \pm 12.1$ & $18.8 \pm 17.8$ \\
Ciliate B $\left(\mu \mathrm{g} \mathrm{L}^{-1}\right)$ & $69.2 \pm 25.8$ & $174.0 \pm 162.5$ & $362.4 \pm 178.5$ & $110.8 \pm 103.4$ & $191.6 \pm 166.2$ \\
Rotifer N (ind. L & $107.9 \pm 67.4$ & $490.0 \pm 457.8$ & $834.0 \pm 355.5$ & $306.7 \pm 305.9$ & $480.9 \pm 398.3$ \\
Rotifer B $\left(\mu \mathrm{g} \mathrm{L}^{-1}\right)$ & $46.5 \pm 21.8$ & $193.0 \pm 192.6$ & $603.1 \pm 336.7$ & $105.7 \pm 88.6$ & $384.1 \pm 407.5$ \\
Crustacean N (ind. L $\left.{ }^{-1}\right)$ & $2.3 \pm 1.9$ & $13.1 \pm 13.0$ & $9.5 \pm 5.8$ & $20.3 \pm 12.7$ & $27.6 \pm 41.4$ \\
Crustacean B $\left(\mu \mathrm{g} \mathrm{L}^{-1}\right)$ & $31.2 \pm 28.4$ & $221.9 \pm 297.8$ & $79.7 \pm 22.8$ & $298.6 \pm 229.0$ & $545.8 \pm 935.9$ \\
\hline
\end{tabular}

\section{Ciliates}

Ciliate numbers fluctuated between $3.5 \pm 0.9$ and $65.8 \pm 11.8 \times 10^{3}$ ind. $\mathrm{L}^{-1}$ (Fig. 4a). The lowest values were observed in March, while the highest in April. Ciliate biomass ranged from $34.3 \pm 7.9 \mu \mathrm{g} \mathrm{L}^{-1} \quad(15 \quad$ October $)$ to $636.9 \pm 77.0 \mu \mathrm{g} \mathrm{L}^{-1}$ (10 April). Throughout most of the ice-covered period, the numbers showed a decreasing trend, while the biomass remained at a more or less constant level. At the end of March, both the numbers and biomass of ciliates increased considerably. The highest variability, both between sites (Fig. 4a) and sampling dates (Table 1), was observed in March (CV up to $46 \%$ and $112 \%$, respectively). Ciliate numbers and biomass were lower in February than in ice-free months (Table 1). However, the differences in ciliate numbers and biomass were significant between February and April only $(Z=3.45, p=0.006$ and $Z=4.10, p=0.0004$, respectively). Although ciliate biomass was higher in March than in July, the difference was not statistically significant $(Z=1.65, p=0.993)$.

Oligotrichida and Prostomatida were the dominant ciliate orders during most of the studied period (Fig. 5a). Only on 8 October, cyclotrichids (omnivorous Mesodinium spp.) formed a substantial part of the total numbers. In February and April, oligotrichs were mainly represented by small species of the genus Rimostrombidium (primarily Rimostrombidium humile), in March by larger species of the genus Strombidium, while in July and October by Halteria grandinella. In all months, Prostomatida were 

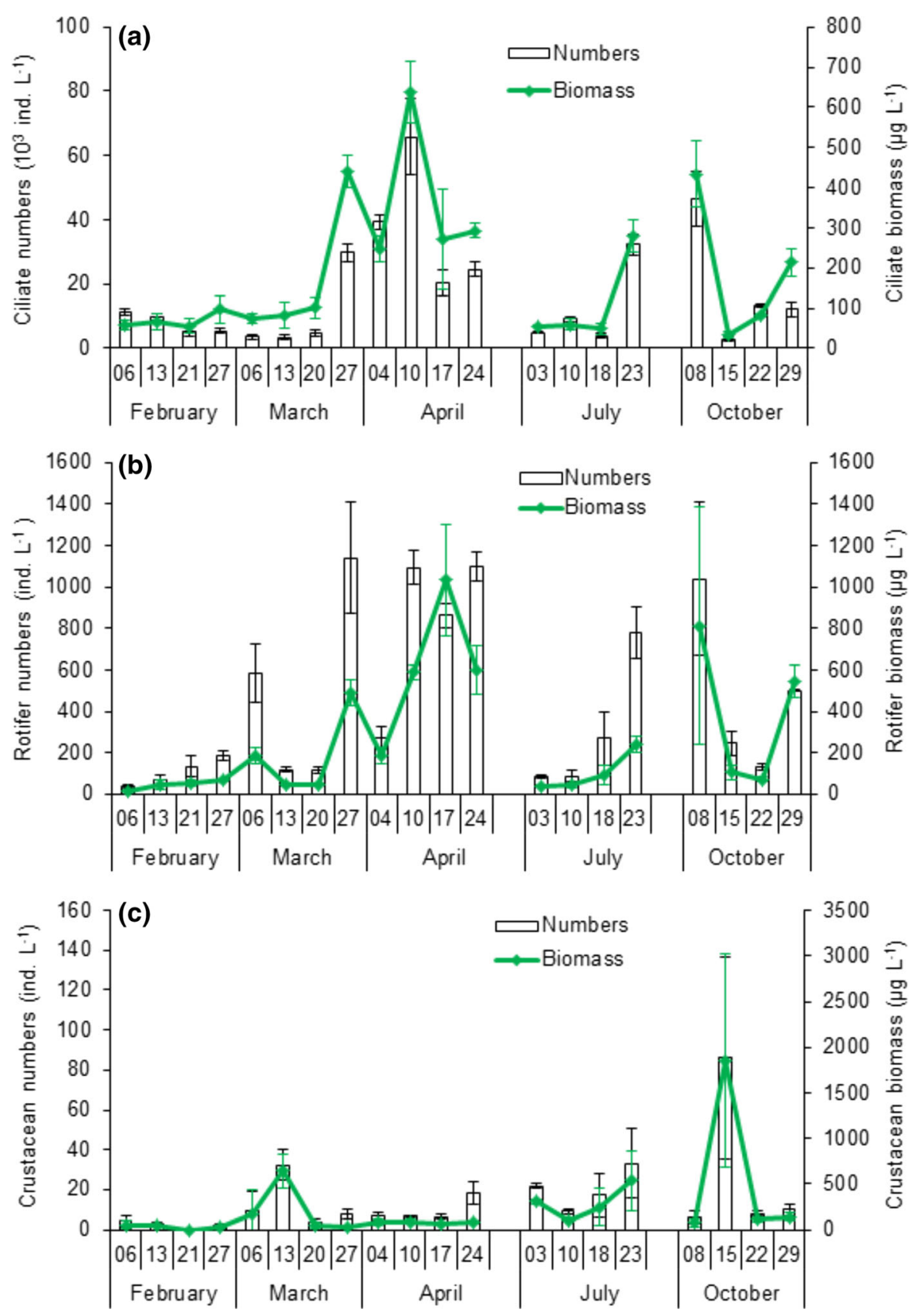

Fig. 4 The numbers and biomass of ciliates (a), rotifers (b), and crustaceans (c) in the Łuczański Canal. Mean values from 3 sites \pm standard deviations

represented by Balanion planctonicum, except in October, when small Urotricha spp. dominated.
Fig. 5 Contribution of ciliate taxonomic groups (a), rotifer species (b), and crustacean taxonomic groups (c) to the total ciliate, rotifer and crustacean numbers, respectively, in the Łuczański Canal 


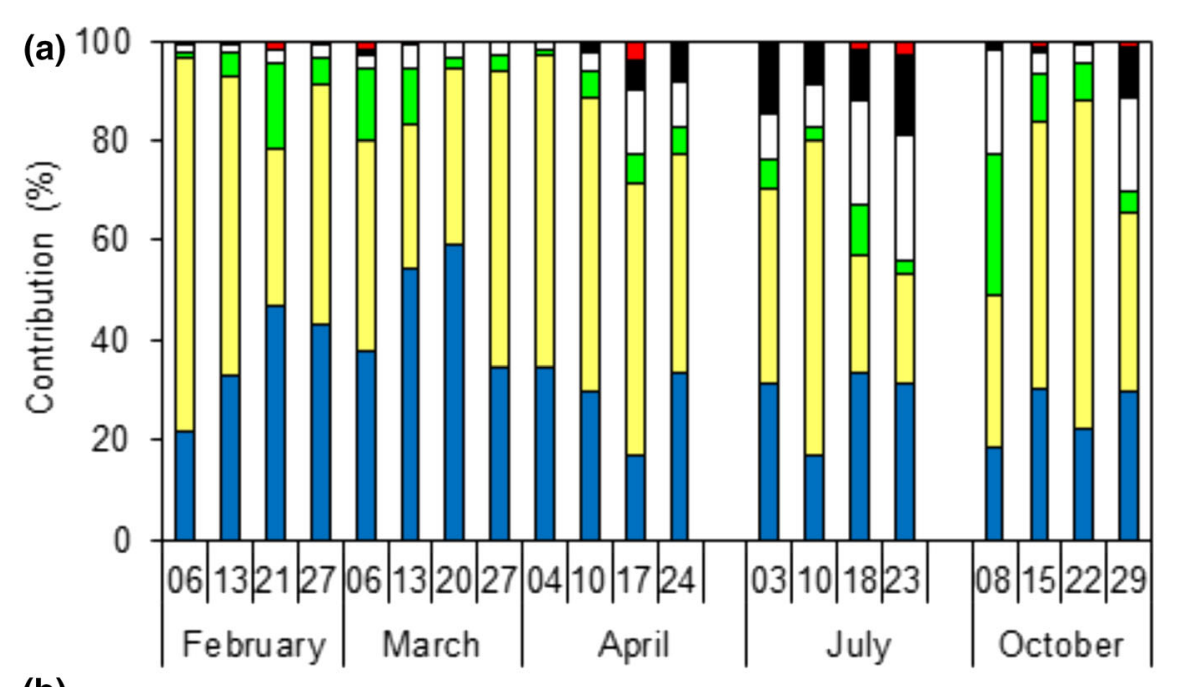

口Others

-Peritrichia

$\square$ Scuticociliates

$\square$ Gymnostomatea

口Prostomatida

$\square$ Oligotrichida

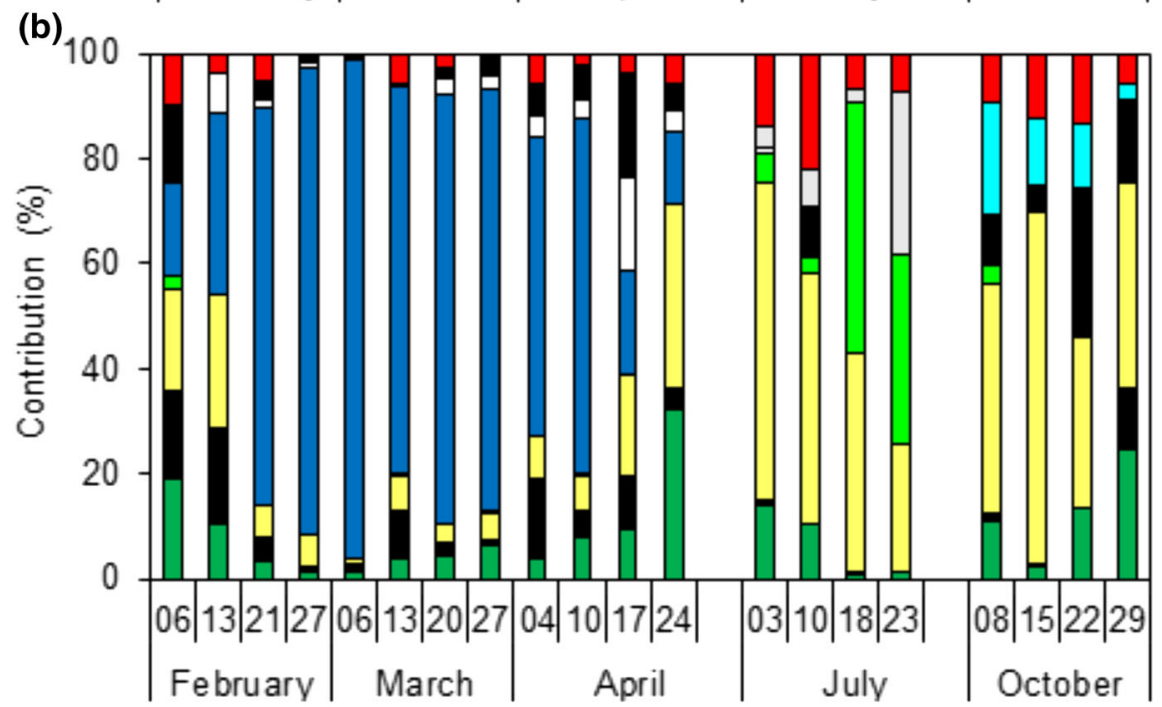

$\square$ Others

$\square$ Anuraeopsis fissa

$\square$ Pompholyx sulcata

- Synchaeta lakowitziana

$\square$ Synchaeta pectinata

$\square$ Notholca spp.

$\square$ Trichocerca spp.

$\square$ Polyarthra spp.

- Keratella quadrata

$\square$ Keratella cochlearis

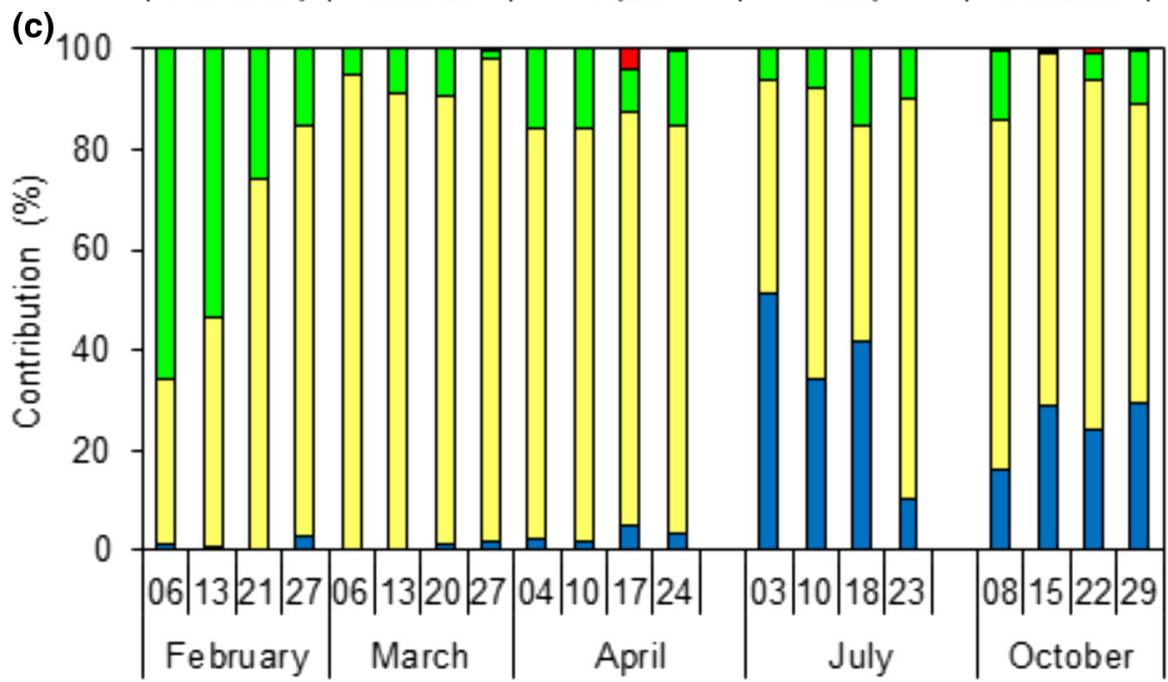
- Harpacticoida
$\square$ Calanoida
$\checkmark$ Cyclopoida
-Cladocera


Rotifers

The lowest rotifer numbers $\left(38.0 \pm 7.0\right.$ ind. $\left.\mathrm{L}^{-1}\right)$ and biomass $\left(19.6 \pm 2.7 \mu \mathrm{g} \mathrm{L}^{-1}\right)$ were recorded at the beginning of the study (Fig. 4b). The highest numbers $\left(1139.7 \pm 267.6\right.$ ind. $\mathrm{L}^{-1}$ ) were observed at the end of March. Similarly, high values were also observed in April and October. The rotifer biomass reached a maximal value of $1033.4 \pm 268.0 \mu \mathrm{g} \mathrm{L}^{-1}$ on 17 April. The high variability between sites (Fig. 4b) was recorded in October (CV up to $36 \%$ for numbers and $70 \%$ for biomass), while between sampling dates (Table 1) in July (for numbers CV up to 100\%) and in October (for biomass CV up to 106\%). Rotifer numbers and biomass were significantly lower in February than in April $(Z=4.77, p<0.0001$ and $Z=4.90, \quad p<0.0001$, respectively) and October $(Z=3.08, p=0.021$ and $Z=3.53, p=0.004$, respectively). The rotifer biomass in March was significantly lower than in April $(Z=3.14, p=0.017)$.

On the first sampling occasion, five species (Keratella cochlearis, K. quadrata, Polyarthra spp., Notholca spp., Synchaeta lakowitziana) co-dominated (Fig. 5b). Throughout the ice-covered period and during the first half of April, species of the genus Notholca (primarily N. squamula) were the most abundant. In summer and autumn, species of the genera Polyarthra and/or Trichocerca dominated.

\section{Crustaceans}

The numbers and biomass of crustaceans followed almost the same pattern, ranging from $0.6 \pm 0.2$ ind. $\mathrm{L}^{-1}$ to $86.0 \pm 50.7$ ind. $\mathrm{L}^{-1}$ and from $2.68 \pm 2.85 \mu \mathrm{g} \mathrm{L}^{-1}$ to $1854.2 \pm 1177.4 \mu \mathrm{g} \mathrm{L}^{-1}$, respectively (Fig. 4c). The lowest values were recorded in February, while the highest in October. During the ice-covered period, the numbers and biomass were generally low with one distinct peak on 13 March. The highest variability between sites (Fig. 4c) was found in March (CV up to $113 \%$ for numbers and $161 \%$ for biomass), while between sampling dates (Table 1) in October ( $\mathrm{CV}$ up to $150 \%$ for numbers and $171 \%$ for biomass). Crustacean numbers were significantly lower in February than in open water months $(Z=3.80, p=0.0015$ for April, $Z=5.91, p<0.0001$ for July and $Z=3.48, p=0.005$ for October), while in March, numbers were significantly higher than those in April $(Z=4.05$, $p=0.0005)$. Crustacean biomass was significantly lower in February than in both July $(Z=4.72$, $p<0.0001)$ and October $(Z=4.13, p=0.0004)$.

Cyclopoida were the dominant component of the crustacean community during most of the studied period (Fig. 5c). During the ice-covered period, their contribution to the total crustacean numbers markedly increased, while the contribution of calanoid copepods decreased. Cladocerans formed a substantial part of the total numbers in summer and autumn. Within Cyclopoida, Acanthocyclops venustus was a dominant species in winter and spring with the highest abundance ( 25 ind. $\mathrm{L}^{-1}$ ) on 13 March. Other Cyclopoida, Thermocyclops sp. and Mesocyclops leuckarti, dominated in July and October. Calanoid copepods were represented by two species, namely Eudiaptomus gracilis and E. graciloides. The cladoceran Diaphanosoma brachyurum dominated in summer, while was absent in autumn when Daphnia cucullata and Ceriodaphnia quadrangular constituted a substantial part of both the total cladoceran numbers and biomass. Among a total of 24 cladoceran species found during summer and autumn, 11 species were typical of the littoral zone. It should be emphasised that a single specimen of relict cladoceran Bythotrephes brevimanus was noted in July. During the icecovered period, cladocerans were represented by Bosmina longirostris, Chydorus sphaericus, Daphnia longispina, Alona guttata and D. cucullata. However, the latter two species appeared at the end of March, when the water temperature slightly increased.

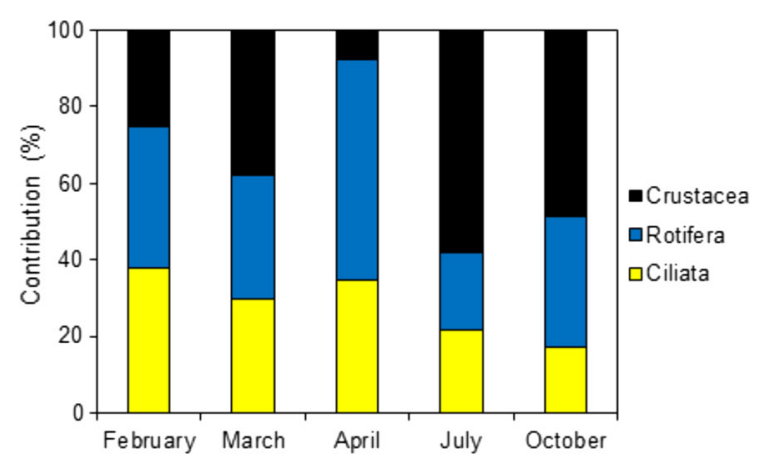

Fig. 6 Mean contribution of ciliates, rotifers, and crustaceans to the total zooplankton biomass in the Łuczański Canal 
Ciliate-metazooplankton relationships

In February, ciliates were the dominant group among zooplankton, constituting $47 \%$ of the total biomass (Fig. 6). Rotifers clearly dominated in April (58\%), while crustaceans in March, June and October, accounting for 38,58 and $49 \%$ of the total zooplankton biomass, respectively. The trophic relationships between the ciliate, rotifer and crustacean biomass differed among the studied months (Fig. 7). In February, ciliates were positively, but weakly correlated with chlorophyll $a$ and cladocerans, while calanoids were negatively and strongly correlated with ice cover, chlorophyll $a$ and rotifers (Fig. 7a). In March, ciliates were positively and strongly correlated with chlorophyll $a$ and cladocerans as well as slightly weaker with rotifers (Fig. 7b). In this month, ciliates, rotifers and
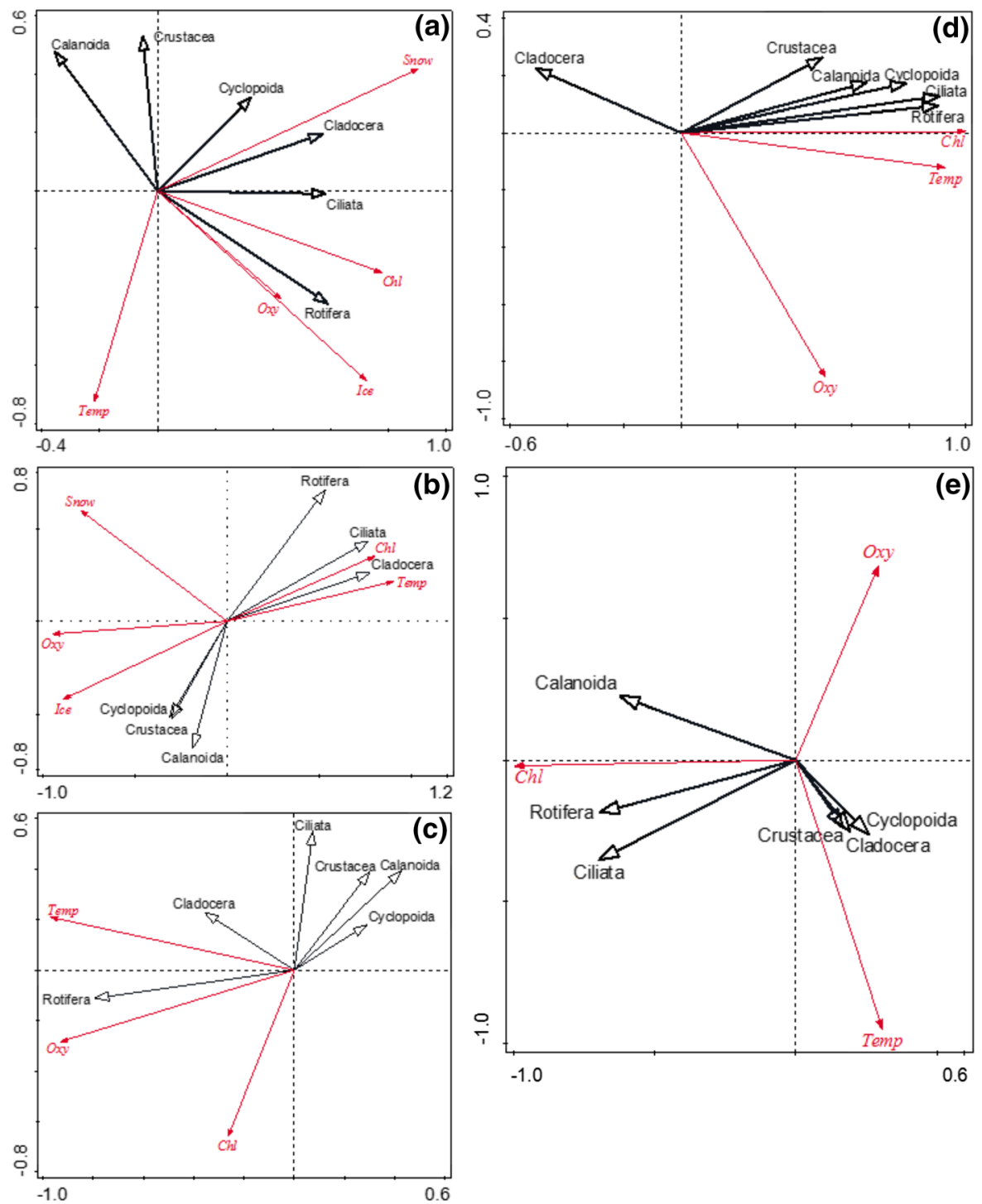

Fig. 7 The relationships between the biomass of ciliates and metazooplankton and abiotic parameters based on principal component analysis (PCA) in February (a), March (b), April (c), June (d) and October (e) in the Łuczański Canal. Temptemperature, Oxy-dissolved oxygen, $\mathrm{Chl}$-chlorophyll $a$. $\mathrm{Cu}-$ mulative explained variation for two first axes in February is

$90.1 \%$ (65.9 and 24.2\%, respectively), in March is $94.0 \%$ (74.9 and $19.1 \%$, respectively), in April is $93.1 \%$ (84.1 and 9.0\%, respectively), in July is $99.8 \%$ (99.2 and $0.6 \%$ respectively), while in October it is $99.6 \%$ (92.9 and 6.7\%, respectively 
cladocerans were negatively related to the ice cover and positively related to temperature. In April, the studied groups of organisms were not related to each other (Fig. 7c). In contrast, in July, zooplankton communities were closely related to each other and to chlorophyll $a$ (Fig. 7d), while in October, ciliates were positively related to rotifers (Fig. 7e).

\section{Discussion}

In this study, the results for 2 months with ice cover (February and March) were used as a comparison for the ice-free seasons' results (April, July, October). Our study showed that the abundance, taxonomic composition, contribution of planktonic groups of organisms to the total zooplankton biomass, and ciliate-metazoan trophic coupling can change considerably under the ice-covered period. An increase in the concentration of chlorophyll $a$ and abundances of ciliates, rotifers and crustaceans observed in March suggest that time was probably a cue that initiated zooplankton development despite the low water temperature and the presence of ice cover. High ciliate and rotifer abundances in April could be the result of low grazing pressure by crustaceans, whose abundances at this time were relatively low both mean numbers and biomass were lower than under ice cover in March. The maximal values of crustacean numbers and biomass in October could be the result of favourable environmental conditions.

Under-ice ciliate community

Although pelagic ciliates are an important component of plankton, accounting for up to $30-60 \%$ of the total zooplankton biomass in summer (Pace and Orcutt 1981; Beaver and Crisman 1990), they are rarely included in routine plankton studies. Little is known about their share in the total zooplankton biomass in freshwater ecosystems during the ice-covered period. It is documented that in eutrophic lakes, ciliates can form only a small part (2.7-7.4\%) of the total winter biomass (Kalinowska et al. 2017). Our data showed that during the ice-covered period ciliates formed on average $47 \%$ and $30 \%$ of the total zooplankton biomass in February and March, respectively. Their proportion was considerably lower in summer (mean $22 \%$ ) and even in spring (mean 35\%).
It has been shown that the winter ciliate community is mainly represented by oligotrichs and small-sized prostomatids (Ventelä et al. 1998; Kalinowska and Grabowska 2016; Kalinowska et al. 2017, 2019). In this study, ciliates were numerically dominated by small prostomatid Balanion planctonicum and Urotricha furcata. Large-sized oligotrich Strombidium spp. prevailed in the total ciliate biomass.

Under-ice metazoan communities

Results of some studies indicated that rotifers can reach relatively high abundances during the icecovered period (Kalinowska and Grabowska 2016) and may constitute about $90 \%$ of total abundance and $80 \%$ of the total biomass in winter zooplankton (Virro et al. 2009). We found that rotifers constituted only about $33 \%$ of the total biomass in winter (in both months). According to the literature data, the winter rotifer community is characterised by low diversity and high dominance of a few species, mainly Polyarthra dolichoptera both in abundance and biomass (Virro et al. 2009). Some other dominant rotifer species include Polyarthra species (Polyarthra vulgaris, P. remata) and Kellicottia longispina (Jensen 2019), Synchaeta tremula-oblonga group, Notholca spp., Keratella cochlearis (Dokulil et al. 2014), Filinia terminalis and Filinia longiseta (Ventelä et al. 1998). In this study, Notholca squamula dominated both in the total numbers and biomass in winter.

Literature data show that crustaceans are composed mainly of calanoid and cyclopoid copepods (Eudiaptomus gracilis, E. graciloides, Acanthocyclops venustus) and their juveniles during the ice-covered period (Agbeti and Smol 1995; Ventelä et al. 1998; Bertilsson et al. 2013; Dokulil et al. 2014; Kalinowska and Grabowska 2016; Grosbois et al. 2017; Jensen 2019), accounting for $92 \%$ of the crustacean zooplankton densities (Twiss et al. 2012). In some lakes, for instance in the oligotrophic lake in Norway, cladocerans (Daphnia longispina, Bosmina longispina and Holopedium gibberum) may be an important component of winter crustacean biomass (Grosbois et al. 2017; Jensen 2019). In our study, although cladocerans were present during the ice-covered period, their contribution to the total numbers and biomass did not exceed $8 \%$. The dominant species in winter months was cyclopoid Acanthocyclops venustus. This species is characteristic of small water bodies, ponds, 
groundwaters and wells (Błędzki and Rybak 2016). It is also interesting that females of A. venustus were present without eggs, despite the presence of numerous adult forms and nauplii. The presence of "packets" of eggs in the water indicates that this species can lay eggs directly into the water.

\section{Tropic coupling between ciliates and metazoans}

Winter zooplankton dynamics depend on ice conditions (Dokulil et al. 2014). Some studies suggested that during the ice-covered months, copepods may rely on previously accumulated lipid reserves for reproduction that would not be possible only by primary production (Schneider et al. 2016). Therefore, zooplankton require alternative and additional carbon sources (Jensen 2019). Terrestrial organic matter and bacteria cannot be used as alternative energy sources to maintain zooplankton during low primary production (Grosbois et al. 2017), but benthic algae can sustain zooplankton metabolic demands and growth during long winters (Karlsson and Säwström 2009). In our study, a strong negative correlation between calanoids and both ice cover and chlorophyll $a$ suggest that crustacean species were mainly controlled by physical parameters in addition to phytoplankton. A weak positive correlation between ciliates and chlorophyll $a$ indicates that bottom-up control by resources was more important than top-down control by zooplankton predation in regulating the ciliate community under the ice in a small and shallow canal. Phytoplankton community composition affects ciliate growth and species structure (Li et al. 2016). Some studies (e.g. Zingel and Nõges 2010) demonstrate that in a shallow eutrophic lake, the ciliates were clearly bottom-up controlled most of the time, but in winter, they did not correlate significantly with any of the chemical and biological factors. In contrast, in a shallow eutrophic lake in eastern China, both small and large ciliates (prostomatids and oligotrichs) were strongly suppressed by both cladocerans and copepods (Li et al. 2017). In March, strong correlations between ciliates and other groups of organisms suggest that crustaceans and rotifers may include ciliates as an important part of their diets during the ice-covered period. In April, the weak relationships between the studied groups of organisms may suggest a low grazing pressure by crustaceans on ciliates and rotifers. As a consequence, ciliates and rotifers can reach high abundances.

Most studies on the ciliate-metazoa trophic coupling were performed during summer. Some authors demonstrated that zooplankton clearance rate on individual ciliate taxa is size-dependent and is greatest for small taxa $(<20 \mu \mathrm{m}$ in size) (Carrick et al. 1991), whereas others reported that crustaceans mainly graze on large-sized predacious ciliates $(>100 \mu \mathrm{m})$, rather than on smaller ciliates $(<20-40 \mu \mathrm{m}$ ) (Agasild et al. 2013). Copepod clearance rates are higher on oligotrichs than other ciliate species (Burns and Gilbert 1993; Hansen 2000). Behavioural differences among ciliates and the presence of other ciliates cause differences in ciliate susceptibility to predation (Burns and Gilbert 1993). Recent studies carried out in Lake Baikal have shown that endemic copepod Epischura baikalensis can obtain nearly all (96-98\%) of their ingested carbon from ciliates (Moore et al. 2019). It was also found that the most commonly consumed species was a mixotrophic oligotrich Limnostrombidium viride (Moore et al. 2019). This species dominated the total ciliate biomass during summer in the present study. Positive and strong correlations between all the groups of organisms may indicate the crucial role of ciliates in the diet of rotifers and crustaceans during summer. However, other studies showed only some weak top-down regulation of ciliates in summer (Zingel and Nõges 2010).

In October, ciliates were mainly related to rotifers, suggesting that predation by rotifers might be a major force in structuring the ciliate community, leading to a decrease in their abundance. A similar relationship between ciliates and rotifers has been reported in peatlands (Bielańska-Grajner et al. 2011). The impact of rotifers on ciliates is species-specific and may vary both among closely related ciliates of similar cell size and among different species of the same rotifer genus (Weisse and Frahm 2001, 2002). Our study suggests that small species $(<20 \mu \mathrm{m})$ of the genus Urotricha, which dominated the total ciliate numbers, could probably be the food resource not only for Keratella cochlearis and K. quadrata, but also for some other rotifer species. 


\section{Conclusions}

The results demonstrate that months with ice cover differed significantly in chlorophyll $a$ concentrations, cyclopoid numbers, taxonomic composition of crustaceans and percentage share of the studied groups of organisms in the total zooplankton biomass. Our results also highlight that time may be a signal initiating zooplankton development despite the low water temperature and the presence of ice cover. Ciliates composed the major part of the total zooplankton biomass during the ice-covered period when crustaceans occurred in very low densities. The trophic relationships between ciliates and metazooplankton differed between months with ice-cover. In February, bottom-up control by resources seems to be more important than top-down control by zooplankton grazing pressure in structuring the ciliate community. In March (ice-covered period), crustaceans and rotifers may include ciliates as an important part of their diets. In spring, the studied groups of organisms were not related to each other in contrast to summer, when zooplankton communities were closely related to each other. In autumn, rotifers may play an important role in controlling ciliates.

Acknowledgements We would like to thank Waldemar Kozłowski, Adam Mańko, Jan Rola and Piotr Traczuk for their help in the field sampling. This research was financed through the Stanislaw Sakowicz Inland Fisheries Institute in Olsztyn within its statutory research activity (topic no. S-011). We would like to thank the anonymous reviewers for their valuable comments, which greatly helped us to improve the manuscript.

\section{Compliance with ethical standards}

Conflict of interest The authors declare that they have no conflict of interest.

Open Access This article is licensed under a Creative Commons Attribution 4.0 International License, which permits use, sharing, adaptation, distribution and reproduction in any medium or format, as long as you give appropriate credit to the original author(s) and the source, provide a link to the Creative Commons licence, and indicate if changes were made. The images or other third party material in this article are included in the article's Creative Commons licence, unless indicated otherwise in a credit line to the material. If material is not included in the article's Creative Commons licence and your intended use is not permitted by statutory regulation or exceeds the permitted use, you will need to obtain permission directly from the copyright holder. To view a copy of this licence, visit http://creativecommons.org/licenses/by/4.0/.

\section{References}

Adrian R, Schneider-Olt B (1999) Top-down effects of crustacean zooplankton on pelagic microorganisms in a mesotrophic lake. J Plankton Res 21:2175-2190

Agasild H, Zingel P, Karus K, Kangro K, Salujõe J, Nõges T (2013) Does metazooplankton regulate the ciliate community in a shallow eutrophic lake? Freshw Biol 58:183-191. https://doi.org/10.1111/fwb.12049

Agbeti MD, Smol JR (1995) Winter limnology: a comparison of physical, chemical and biological characteristics in two temperate lakes during ice cover. Hydrobiologia 304:221-234

Arndt H (1993) Rotifers as predators on components of the microbial web (bacteria, heterotrophic flagellates, ciliates)—a review. Hydrobiologia 255(256):231-246

Beaver JR, Crisman TL (1990) Seasonality of planktonic ciliated protozoa in 20 subtropical Florida lakes of varying trophic state. Hydrobiologia 190:127-135

Bertilsson S, Burgin A, Carey CC, Fey SB, Grossart H-P, Grubisic LM, Jones ID, Kirillin G, Lennon JT, Shade A, Smyth RL (2013) The under-ice microbiome of seasonally frozen lakes. Limnol Oceanogr 58:1998-2012. https://doi. org/10.4319/lo.2013.58.6.1998

Bielańska-Grajner I, Mieczan T, Cudak A (2011) Co-occurrence of ciliates and rotifers in peat mosses. Pol J Environ Stud 20:533-540

Błędzki LA, Rybak JI (2016) Freshwater crustacean zooplankton of Europe. Springer, Berlin. https://doi.org/10.1007/ 978-3-319-29871-9

Bottrell HH, Duncan A, Gliwicz ZM, Grygierek E, Herzig A, Hillbricht-Ilkowska A, Kurasawa H, Larsson P, Węgleńska $\mathrm{T}$ (1976) A review of some problems in zooplankton production studies. Norw J Zool 24:419-456

Brett MT, Wiąckowski K, Lubnov FS, Mueller-Solger A, Elser JJ, Goldman CR (1994) Species-dependent effects of zooplankton on planktonic ecosystem processes in Castle Lake, California. Ecology 75:2243-2254

Burns CW, Gilbert JJ (1993) Predation on ciliates by freshwater calanoid copepods: rates of predation and relative vulnerabilities of prey. Freshw Biol 30:377-393

Burns CW, Schallenberg M (2001) Calanoid copepods versus cladocerans: consumer effects on protozoa in lakes of different trophic status. Limnol Oceanogr 46:1558-1565

Carrick HJ, Fahnenstiel GL, Stoermer EF, Wetzel RG (1991) The importance of zooplankton-protozoan trophic couplings in Lake Michigan. Limnol Oceanogr 36:1335-1345

Chróst RJ, Adamczewski T, Kalinowska K, Skowrońska A (2009) Effect of organic phosphorus and nitrogen enrichment of mesotrophic lake water on dynamics and diversity of planktonic microbial communities-DNA and protein case studies (mesocosm experiments). Pol J Microbiol 58:163-180

Dokulil MT, Herzig A (2009) An analysis of long-term winter data on phytoplankton and zooplankton in Neusiedler See, a shallow temperate lake, Austria. Aquat Ecol. https://doi. org/10.1007/s10452-009-9282-3

Dokulil MT, Herzig A, Somogyi B, Vörös L, Donabaum K, May L, Nõges T (2014) Winter conditions in six European 
shallow lakes: a comparative synopsis. Est $\mathrm{J}$ Ecol 63:111-129. https://doi.org/10.3176/eco.2014.3.01

Ejsmont-Karabin J (1998) Empirical equations for biomass calculation of planktonic rotifers. Pol Arch Hydrobiol 45:513-522

Ejsmont-Karabin J, Gorelysheva Z, Kalinowska K, Węgleńska $\mathrm{T}$ (2004) Role of zooplankton (Ciliata, Rotifera and Crustacea) in phosphorus removal from cycling: lakes of the river Jorka watershed (Masuria Lakeland, Poland). Pol J Ecol 52:275-284

Foissner W, Berger H, Schaumburg J (1999) Identification and ecology of limnetic plankton ciliates. Informationberichte des Bayer. Landesamtes für Wasserwirtschaft, München, p 793

Golterman HL (1969) Methods for chemical analysis of fresh waters. IBP handbook no 8. Blackwell Scientific Publications, Oxford and Edinburgh

Grosbois G, Mariash H, Schneider T, Rautio M (2017) Underice availability of phytoplankton lipids is key to freshwater zooplankton winter survival. Sci Rep 7:11543. https://doi. org/10.1038/s41598-017-10956-0

Hansen A-M (2000) Response of ciliates and Cryptomonas to the spring cohort of a cyclopoid copepod in a hypertrophic lake. J Plankton Res 22:185-203. https://doi.org/10.1093/ plankt/22.1.185

Jack JD, Gilbert JJ (1997) Effects of metazoan predators on ciliates in freshwater plankton communities. J Eukaryot Microbiol 44:194-199

Jensen TC (2019) Winter decrease of zooplankton abundance and biomass in subalpine oligotrophic Lake Atnsjøen (SE Norway). J Limnol 78:348-363. https://doi.org/10.4081/ jlimnol.2019.1877

Jürgens K (1994) Impact of Daphnia on planktonic microbial food webs-a review. Mar Microb Food Webs 8:295-324

Kalinowska K, Grabowska M (2016) Autotrophic and heterotrophic plankton under ice in a eutrophic temperate lake. Hydrobiologia 777:111-118. https://doi.org/10.1007/ s10750-016-2769-8

Kalinowska K, Ejsmont-Karabin J, Rzepecki M, KostrzewskaSzlakowska I, Yu Feniova I, Palash A, Dzialowski AR (2015) Impacts of large-bodied crustaceans on the microbial loop. Hydrobiologia 744:115-125. https://doi.org/10. 1007/s10750-014-2066-3

Kalinowska K, Napiórkowska-Krzebietke A, Bogacka-Kapusta E, Hutorowicz J, Pyka J, Stawecki K, Kapusta A, Chybowski $Ł$ (2017) Microbial and classic food web components under ice cover in eutrophic lakes of different morphometry and fisheries management. Oceanol Hydrobiol Stud 46:271-282. https://doi.org/10.1515/ohs-20170029

Kalinowska K, Napiórkowska-Krzebietke A, Bogacka-Kapusta E, Stawecki K (2019) Comparison of ice-on and ice-off abiotic and biotic parameters in three eutrophic lakes. Ecol Res 34:687-698. https://doi.org/10.1111/1440-1703. 12039

Karlsson J, Säwström C (2009) Benthic algae support zooplankton growth during winter in a clear-water lake. Oikos 118:539-544. https://doi.org/10.1111/j.1600-0706.2008. 17239.x
Kopylov AI, Kosolapov DB (2011) Microbial loop in plankton communities of marine and freshwater ecosystems. Knigograd, Izhewsk

Li J, Chen F, Liu Z, Zhao X, Yang K, Lu W, Cui K (2016) Bottom-up versus top-down effects on ciliate community composition in four eutrophic lakes (China). Eur J Protistol 53:20-30. https://doi.org/10.1016/j.ejop.2015.12.007

Li J, Yang K, Chen F, Lu W, Fang T, Zhao X, Li H, Cui K (2017) The impacts of crustacean zooplankton on a natural ciliate community: a short-term incubation experiment. Acta Protozool 56:289-301. https://doi.org/10.4467/ 16890027AP.17.025.7827

Makhutova ON, Protasov AA, Gladyshev MI, Sylaieva AA, Sushchik NN, Morozovskaya IA, Kalachova GS (2013) Feeding spectra of bivalve mollusks Unio and Dreissena from Kanevskoe Reservoir, Ukraine: Are they food competitors or not? Zool Stud 52:2-10. https://doi.org/10.1186/ $1810-522 X-52-56$

Martin-Creuzburg D, Bec A, von Elert E (2005) Trophic upgrading of picocyanobacterial carbon by ciliates for nutrition of Daphnia magna. Aquat Microb Ecol 41:271-280. https://doi.org/10.3354/ame041271

Moore MV, De Stasio BT Jr, Huizenga K, Silow EA (2019) Trophic coupling of the microbial and classical food web in Lake Baikal, Siberia. Freshw Biol 64:138-151. https://doi. org/10.1111/fwb.13201

Müller H, Geller W (1993) Maximum growth rates of aquatic ciliated protozoa: the dependence on body size and temperature reconsidered. Arch Hydrobiol 126:315-327

Pace ML, Orcutt JD Jr (1981) The relative importance of protozoans, rotifers and crustaceans in a freshwater zooplankton community. Limnol Oceanogr 26:822-830

Radwan S, Bielańska-Grajner I, Ejsmont-Karabin J (2004) Część ogólna, Monogononta- część systematyczna. 32.A. In: Radwan S (ed) Wrotki (Rotifera). Fauna słodkowodna Polski. 32. Łódź: Polskie Towarzystwo Hydrobiologiczne, Uniwersytet Łódzki. Oficyna Wydawnicza Tercja, pp 1-146

Sanders RW, Wickham SA (1993) Planktonic protozoa and metazoa: predation, food quality and population control. Mar Microb Food Webs 7:197-223

Schneider T, Grosbois G, Vincent WF, Rautio M (2016) Carotenoid accumulation in copepods is related to lipid metabolism and reproduction rather than to UV-protection. Limnol Oceanogr 61:1201-1213. https://doi.org/10.1002/ lno. 10283

Sommer U, Adrian R, De Senerpont Domis L, Elser JJ, Gaedke U, Ibelings B, Jeppesen E, Lürling M, Molinero JC, Mooij WM, van Donk E, Winder M (2012) Beyond the plankton ecology group (PEG) model: mechanisms driving plankton succession. Annu Rev Ecol Evol S 43:429-448. https://doi. org/10.1146/annurev-ecolsys-110411-160251

Twiss MR, McKay RML, Bourbonniere RA, Bullerjahn GS, Carrick HJ, Smith REH, Winter JG, D'souza NA, Furey PC, Lashaway AR, Saxton MA, Wilhelm SW (2012) Diatoms abound in ice-covered Lake Erie: an investigation of offshore winter limnology in Lake Erie over the period 2007 to 2010. J Great Lakes Res 38:18-30. https://doi.org/ 10.1016/j.jglr.2011.12.008

Ventelä AM, Saarikari V, Vuorio K (1998) Vertical and seasonal distributions of microorganisms, zooplankton and 
phytoplankton in a eutrophic lake. Hydrobiologia 363:229-240

Ventelä A-M, Wiąckowski K, Moilanen M, Saarikari V, Vuorio K, Sarvala J (2002) The effect of small zooplankton on the microbial loop and edible algae during a cyanobacterial bloom. Freshw Biol 47:1807-1819

Virro T, Haberman J, Haldna M, Blank K (2009) Diversity and structure of the winter rotifer assemblage in a shallow eutrophic northern temperate Lake Võrtsjärv. Aquat Ecol 43:755-764. https://doi.org/10.1007/s10452-009-9276-1

Weisse T, Frahm A (2001) Species-specific interactions between small planktonic ciliates (Urotricha spp.) and rotifers (Keratella spp.). J Plankton Res 23:1329-1338

Weisse T, Frahm A (2002) Direct and indirect impact of two common rotifer species (Keratella spp.) on two abundant ciliate species (Urotricha furcata, Balanion planctonicum). Freshw Biol 47:53-64

Wiackowski K (2000) The role of protozoans in aquatic ecosystems. Kosmos 49:603-615

Wiąckowski K, Kocerba-Soroka W (2017) Selective predation by a harpacticoid copepod on ciliates in phytotelmata: a laboratory experiment. Hydrobiologia 790:13-22. https:// doi.org/10.1007/s10750-016-2941-1
Wiackowski K, Brett MT, Goldman CR (1994) Differential effects of zooplankton species on ciliate community structure. Limnol Oceanogr 39:486-492

Zingel P, Nõges T (2010) Seasonal and annual population dynamics of ciliates in a shallow eutrophic lake. Fundam Appl Limnol Arch Hydrobiol 176(2):133-143. https://doi. org/10.1127/1863-9135/2010/0176-0133

Zingel P, Agasild H, Karus K, Buholce L, Nõges T (2019) Importance of ciliates as food for fish larvae in a shallow sea by and a large shallow lake. Eur J Protistol 67:59-70. https://doi.org/10.1016/j.ejop.2018.10.004

Zöllner E, Santer B, Boersma M, Hoppe H, Jürgens K (2003) Cascading predation effects of Daphnia and copepods on microbial food web components. Freshw Biol 48:2174-2193. https://doi.org/10.1046/j.1365-2426.2003. 01158.x

Publisher's Note Springer Nature remains neutral with regard to jurisdictional claims in published maps and institutional affiliations. 